Wright State University

CORE Scholar

4-2013

\title{
Connecting Social Provisioning and Functional Finance in a Post- Keynesian - Institutional Analysis of the Public Sector
}

\author{
Zdravka Todorova \\ Wright State University - Main Campus, zdravka.todorova@wright.edu
}

Follow this and additional works at: https://corescholar.libraries.wright.edu/econ

Part of the Economics Commons

\section{Repository Citation}

Todorova, Z. (2013). Connecting Social Provisioning and Functional Finance in a Post-Keynesian Institutional Analysis of the Public Sector. European Journal of Economics and Economic Policies: Intervention, 10 (1).

https://corescholar.libraries.wright.edu/econ/217

This Article is brought to you for free and open access by the Economics at CORE Scholar. It has been accepted for inclusion in Economics Faculty Publications by an authorized administrator of CORE Scholar. For more information, please contact library-corescholar@wright.edu. 


\title{
Connecting social provisioning and functional finance in a post-Keynesian-Institutional analysis of the public sector
}

\author{
Zdravka Todorova \\ Department of Economics, Wright State University, Dayton, Ohio, USA
}

This paper establishes connections between the frameworks of social provisioning and functional finance, and discusses a post-Keynesian-Institutionalist theory of the public sector that emerges out of these linkages. The concept of social provisioning has emerged out of Institutional economics, and has been further developed by institutional and other heterodox economists. Its potential as a methodological foundation that connects various heterodox approaches has received some growing attention. Such discussions have not referred in an analytical manner to functional finance. On the other hand, the principles of functional finance have been elaborated and developed outside an explicit grounding in a social provisioning framework. The article specifies further the concept of social provisioning and discusses functional finance within such a framework. The framework of functional finance gains a structural and institutional grounding which enables a deeper and more critical conceptualization of the public sector.

Keywords: social provisioning, functional finance, social classes

JEL codes: $B 52, E 60, H 60, P 16$

\section{INTRODUCTION}

The concept of social provisioning has emerged out of Institutional economics (Gruchy 1987; Nelson 1993; Dugger 1996), and has been further developed by Institutional and other heterodox economists (Power 2004; Lee 2010; 2011; Jo 2011). Its potential as a methodological foundation that connects various heterodox approaches has received growing attention. Such discussions have not referred in an analytical manner to functional finance. Nevertheless, the principles of functional finance have been elaborated and developed outside an explicit grounding in a social provisioning framework. This article specifies further the concept of social provisioning and discusses functional finance within such a framework. Functional finance gains a structural and institutional grounding which enables a deeper and more critical conceptualization of the public sector. The established connections between the frameworks of social provisioning and functional finance provide the grounds of a post-Keynesian-Institutional analysis of the public sector.

The intellectual roots of Institutionalism and post-Keynesianism can be found in traditions that emphasize the wealth of nations, accumulation, full employment, and social relationships. These traditions study the process that provides the flow of goods and 
services required by society to meet the needs of those who participate in its activities. Any culture has to engage in social provisioning - providing for the material means of life which results in economic activities that generate the flow of goods and services that is necessary to meet the biological and socially-created needs of individuals and to maintain various social values.

The framework of social provisioning emphasizes processes and human agency in cultural context and historical time, and enables the exploration of evolution of resources, production, and consumption patterns, as well as of the socio-cultural meaning of activities that constitute social provisioning (Gruchy 1987; Nelson 1993; Dugger 1996; Power 2004; Lee 2010, 2011; Jo 2011). The social provisioning process is a concept which is broader than market exchange for three main reasons: (1) it is based on the connections between production, consumption, and distribution; (2) it encompasses non-market activities; and (3) social provisioning is enmeshed in the broader culture and ecosystems.

Below I delineate one way to look at the economy from a perspective based on the concept of social provisioning. The purpose is to ground the theory of the public sector in this framework, and to root the principles of functional finance in a deeper socioeconomic analysis.

\section{SOCIAL PROVISIONING: SURPLUS AND CONFLICTS}

Production is a circular flow and all intermediate capital goods are produced inputs. These are interconnected in a technically specific manner and are viewed as nonsubstitutable and relatively scarce factors of production. Some of the outputs replace the goods and services used up in production, and the remainder constitute the social surplus to be used for household consumption, private fixed investment, and government services. The generation and distribution of the produced surplus within specific social relations are the central organizing concepts of economics as the study of social provisioning. The social provisioning process is generated and directed by social organizations: business enterprises, the state, and households. These are not just sectors of the economy, but embody particular power relations.

Consequently, the identification of a 'public sector' necessitates the delineation of the power relations and social conflicts. Social provisioning organized around, and directed by, the decisionmaking within the business enterprise entails conflict rather than harmony. From an institutionalist perspective three main social conflicts can be delineated.

First, there is a contradiction between production of profits and production of use values, or as described by Veblen (1921), between business based on pecuniary valuation (the price system) and industry based on technological valuation (the engineer's view). Prices and output are determined independently of each other, and there is no or little relation between prices and sales. Prices are not functioning as signals and do not coordinate economic activity, nor do they allocate resources. Managerial price setting, investment projects, and production and employment targets are strategic decisions designed to meet specific goals of the business enterprises (Lee 2010). Business enterprises launch product lines in order to achieve various business goals, which may or may not correspond to the households' need to secure livelihood. Households choose out of a given set of goods and services that have been determined independently of them. Satisfaction of consumption needs/wants is a by-product of the business enterprise and the state's activities (Veblen 1919 [2005]; 1921). 'Use values are only a coincidence, and not an end in business activity. Private initiative means business enterprise, not industry ... [T] he profits of business 
come out of the product of industry; and industry is controlled, accelerated and slowed down with a view to business profits' (Veblen 1919: 97). Consequently, private sector investment ensures the reproduction of business enterprises and capitalist households, but not necessarily the survival of the population. Given the conflict between 'making goods' and 'making money,' chronically the generated effective demand is inadequate to maintain full employment - unemployment is persistent.

Second, as a result of business management creating an 'assured strategic advantage for any given business concert there is a claim on community's output - a "vested interest" - a marketable right to get something for nothing' (Veblen 1919 [2005]: 99-100). Veblen calls this vested right in income stream 'free income' because it is a claim on the output and industrial arts produced by the community, which is created by virtue of salesmanship, restriction of supply, and seizure of natural resources. Furthermore, if the claim on income stream is expected to continue, the vested interest is capitalized, and intangible assets are created to be traded or used as collateral and enlarge the claims on social surplus.

... [W] hen once a run of free income has been capitalized and docketed as an asset it becomes a legitimate overhead charge, and it is then justly to be counted among necessary costs and covered by the price which consumers should reasonably pay ... Such finding has come to be a fairly well settled matter of course both among the officials and among the law-abiding investors... (Veblen 1919 [2005]: 103) ${ }^{1}$

Third, all this comes as a cost to the community since the monetary production process involves the creation of social costs that are not merely externalities, or exceptions, but are endemic to the operation of the business enterprise (Kapp 1963 [1950]; Swaney/ Evers 1989; Berger 2009). Social costs cannot be offset by imputed monetary values, since the damages can be irreversible or not readily identifiable. Nor should social costs be measured based on subjective valuation: '...in all matters of social evaluation, we would be on safer grounds if we could rely on objective standards of social minima and measure social costs in terms of shortfalls or deficiencies from such minima' (Kapp 1963 [1950]: 23). The notion of social minima '...facilitates the formulation of aims and priorities which are accessible to scientific interpretation and the pragmatic test' (Kapp 1963 [1950]: 203). As discussed below, the institutional instrumental theory of value is helpful for defining social minima, as well as for assessing the magnitude of social costs.

The above conflicts emerge from the normal operation of business - fraud is not even considered here. Their manifestation is the production of waste as a part of generating the social surplus. In the Veblenian sense, waste is '... expenditure that does not serve human life or human well-being on the whole ... and occurs on the ground of an invidious pecuniary comparison' (Veblen 1899 [1994]: 60-61). The problem is that waste generates income, and it is viewed as desirable to individuals.

On the other hand, not all production within the capitalist economy generates monetary income flows. Within households, there are 'produced' goods and services that contribute to the survival of workers and their dependents, but do not generate income. These are qualitatively different from market goods and services, and appear to be secondary or not part of the economy that is centered on monetary valuation, yet their

1. In The Vested Interests and the Common Man, Veblen (1919) argues that the habitual acceptance of this type of intangible property is based on the persistence of eighteenth century notions of liberty and property rights conceived under different conditions of industrial arts and finance (handicraft, and intermediary finance) before the emergence of the corporation. 
'production' requires the purchase of commodities. Labor power is itself a socially produced 'input' (Pichio 1992; Himmelweit 1995; O'Hara 1995; Prasch 2005; Charusheela/Danby 2006; Todorova 2009).

Within the capitalist economy, the reciprocal relations within and between households (such as cooking and care for a family member) cannot be sustained without access to the available social surplus. Non-monetary activities such as domestic work and care activities could serve as a buffer to partially offset worsened households' financial positions, but only to some extent. Households must obtain money through participation in the market process since they do not own the means of production, and have to pay their tax obligation by selling their labor power.

Individual households may be financially responsible for and emotionally vested in raising children and taking care of dependants and workers, but the 'produced' labor power is a result of households' activities, social institutions, social stock of knowledge, and the production and distribution of social surplus. Consequently, even though non-market activities exist within the capitalist social provisioning process, households are not self-sufficient and autonomous entities; they mostly rely on the output, income, and employment determined by business enterprises and the state (Todorova 2009).

The volume and composition of the social surplus are determined by the desire for surplus goods and services by capitalists and the state, rather than by a price mechanism that embodies consumer sovereignty and labor markets. The production of social surplus is not constrained by households' savings. On the contrary, households' financial positions - their ability to save - are constrained by the state's and business enterprises' demand for social surplus.

In the process of accumulation and market expansion, business enterprises, particularly their financial branches and financial institutions, enable households to temporarily circumvent that constraint and to soften the accompanying inequalities. Through undertaking more debt, households meet ever-evolving social needs that cannot be supported fully by their incomes. As a result, household indebtedness and financial fragility are endemic to the capitalist economy.

\section{CLASSES AND POWER}

The distribution of social surplus can be further explored by a delineation of classes. There are two broad classes with respect to capitalist economic activity: those who do not own or control the means of production, and hence do not receive income flows generated from capital; and those who own and control the means of production, and do receive such incomes (Veblen 1919 [2005]; Lee 2010; 2011). Veblen's (1919 [2005]: 160) formulation is: 'the kept classes' and the 'common man'. The division is between:

...those who own wealth enough to make it count, and those who do not ... a division between the vested interests and the common man. It is a division between those who control the conditions of work and the rate and volume of output and to whom the net output of industry goes as free income, on the one hand, and those others who have the work to do and to whom a livelihood is allowed by these persons in control, on the other hand. (Veblen 1919 [2005]: 161)

Veblen defines a vested interest as an established 'right to get something for nothing,' and calls the owners of such a right by the same name, as well as the kept classes. For example, household debt can be classified as a vested interest - as it leads to 'free income' to the financial sector - which is part of the 'kept classes.' 
The common man is "common in the respect that he is not vested with such a prescriptive right to get something for nothing [and] ... because such is the common lot of men...' (Veblen 1919 [2005]: 162). ${ }^{2}$ Veblen (1919 [2005]: 164) details this classification by including professionals who belong to the kept classes ' ... both in sentiment and as regards the circumstances which condition their life and comfort.'

The 'kept classes' include the leisure class, capitalists, rentiers, elite professionals ${ }^{3}$ and political elite. These could also be referred to as the ruling class who actively seek to preserve their social power through engaging in various economic, political, social, and academic activities. This is done through the organization of business enterprises, households, and the state, as well through other social institutions such as think-tanks, education, and the media. The ruling class directs the generation and distribution of the social surplus and public policy. In addition to a superior material standard of living, the capitalist class has the power to maintain ownership and control in order to continue the directing of the social provisioning process for their benefit.

Ultimately the lives of individuals within households who do not own the means of production are greatly affected by those who do. The ruling class is able to control and direct working class lives in a way that benefits them. Members of the working class could not simply decide to not sell their labor and to become part of the capitalist class for two main reasons. First, their financial positions are not sufficiently liquid, and if they stop selling their labor for wage they could not maintain a household as a going concern. The result would be poverty - financial, social, psychological and biological trauma, and death. Second, in order to be able to live without selling their labor, workers would need sufficient collateral or other means to finance the purchase of capital goods. Alternatively, they would need a significant bequest of asset portfolio to join the rentier class. ${ }^{4}$

The 'common men' include the working class and the dependent class. These do participate in various degrees in democratic processes, but their political power does not direct the social surplus - and the level and kind of employment in the economy.

Individuals and households who have no choice but to sell their labor power to those who own the means of production are the working class.

Some members of the working class receive income flows generated from capital gains - but these are not sufficient to maintain them, so they have to continue selling their labor power, and thus are categorized as workers. The distribution of social surplus varies within the working class, giving rise to inequities and socio-economic distinctions within that broad class. These distinctions blur the similarities in position of the various social classes with respect to their place in the social provisioning process, and 'working class consciousness' is subsumed. All individuals in the economy are brought up, socialized, and live within some form of household. Workers live within working class households, and see themselves as being unified or categorized by patterns of consumption, occupations, and social activities rather than by their common role as wage earners. Thus, members of the working class are represented and/or see themselves as being part of culturally specific and socially constructed categories such as: 'middle class,'

2. The notion of class is empirically grounded, and still valid today. See Wolf (2007) for wealth inequality and rising US household debt; and Allegretto (2011) on the widening wealth gap.

3. Such as economists from top-ranking institutions whose advice is sought after by politicians and the media; as well as corporate management, for example.

4. For analysis of intergenerational and short term income mobility in the USA, see Hertz (2006). Also see The State of Working America, Mobility, Economic Policy Institute, available at: http://stateofworkingamerica.org/subjects/mobility/. 
or 'upper middle class,' or 'professionals' formulated around life-styles. Consequently, these socio-cultural characterizations disarticulate the fundamental commonality within members of the working class: their common dependence on money wages.

Small family business enterprises are also part of the working class - since they provide mostly subsistence for their households. Unemployment insurance recipients are part of the working class who could not sell their labor power, but have participated and will eventually be engaged in paid production of the surplus. Furthermore, when providing care for their household members, these workers are in fact participating in the production of the social surplus. Welfare recipients are part of the working class since they are also required to work for pay. Partners who are supported financially by wage-earners and who support workers by engaging in care and household labor are also part of the working class - they partake in the wages of their partners, but are not wage workers themselves. ${ }^{5}$

Members of the ruling class households who are maintained by another household member's capital gains proceeds are in a different position: they are part of the capitalists' or rentiers' consumption activities (Todorova 2009). The differentiation is on the basis of the main source of household income: rent (or capital gains) versus wage earnings. As described by Veblen (1899 [1994]) the leisure class consumes without being engaged in production and is central in supporting the evolutionary process of invidious distinction. Members of this class could participate in the social provisioning process, but they are financially liquid, and engaging in labor would be contrary to their desired social standing. The income flow that supports this exemption from work is generated from 'rent.' Money managers, for example, are part of the leisure class, since they derive their incomes from speculation, rather than production. They, like children or disabled and retired persons, need to be supported by those who produce social surplus.

Children, disabled, and retired persons constitute the dependent class - they need to consume a portion of the social surplus in order to survive, but do not participate currently in its production. Some of that population may be part of the future labor force (children), others have contributed to the creation of the social surplus and stock of knowledge in the past (retirees), or simply could not work. The commonality among these segments of the population is that at a given point in time they need to be supported by those who currently produce the social surplus. The support can be direct - through allotment of workers' wages, or through various transfers. The dependent class is not to be confused with the leisure class.

The leisure class's exemption from work via access to 'free income' serves as an ideal and an ultimate criterion for valuation with respect to assigning social worth (Veblen 1899 [1994]). Social values change to prioritize market activity and monetary valuation - and the economy - comes to be habitually perceived as a separate and autonomous sphere: it becomes disembedded from society (Polanyi 1944 [1957]). Yet, as pointed out above, social provisioning is not restricted to market activities: markets are a subset of social provisioning. As a result, there is social imbalance between private and public sector goods:

Every corner of the public psyche is canvassed by some of the nation's most talented citizens to see if the desire for some merchantable product can be cultivated. No similar process operates on behalf of the non-merchantable services of the state. Indeed, while we take the cultivation of new private wants for granted we would be measurably shocked to see it applied to

5. See Fraad et al. (1994) for a 'feudal household' formulation. 
public services ... A politician or a public servant who dreams up a new public service is a wastrel. Few public offenses are more reprehensible. (Galbraith 1958: 205)

The apparent separation between the economy and the state is accompanied by an ideological separation between the household and the economy (Waller/Jennings 1991: 492). In reality market and non-market activities are linked and interdependent (Jennings 1992; 1994; Todorova 2009). Obfuscating this interdependence is the foundation of neoliberalism, or market fundamentalism. Specifically, a fictitious link between households' saving and aggregate investment emerges, while their role in social provisioning - the reproduction of labor inputs - begins to be seen as 'not the economy'. As noted above, households' ability to save is constrained by the desire of business enterprises and the state to direct expenditures on activities that generate social surplus. Consequently, the neoliberal ideology distorts the picture of how social surplus is generated and distributed, and obscures working households' systemic vulnerability under capitalism.

\section{THE PUBLIC SECTOR AND SOCIAL RESPONSE TO CONFLICT}

The public sector represents a series of responses to the conflicts emerging out of the class structure in the capitalist economy. The discrepancy between the results of capitalist production and the folklore of market fundamentalism give rise to a social response that does not reject capitalist society itself. Instead, the responses (policies and regulations) represent ' ....an effort toward reform of the most egregious excesses of individualistic society, often undertaken in the name of the very social values of fairness, opportunity, and equality that individualistic values both glorify and countervene.' (Waller/Jennings 1991: 494) ${ }^{6}$

In the narrative of market fundamentalism the economy becomes disembedded from social relations. The conceptual construct of a self-regulating market is an attempt to formulate social life using market logic. The public sector is then conceived as a separate non-market sphere in opposition to the private business sector. ${ }^{7}$ Two major fallacies stem from that dualism. First, the dualism obscures the fact that private sector business activity is supported by public policies, regulations, and spending. ${ }^{8}$ Second, it undermines the notion of public interest. As a result, social responses to the conflicts are formulated in ways that prioritize market activity and valuation (thus recasting all human activity as market-like). The analytical apparatus of the business enterprise becomes the dominant model for analysis and policy formulation, and the public sector submits to money prices as a criterion for judging value (Hayden 2006: 16).

Consequently, the idea of public interest is attacked in two ways. First, it is straitjacketed by liberals who conceive only of market solutions. ' 'Making markets work,'

6. See also O’Hara (1995: 113).

7. Karl Polanyi (1944 [1957]: 149) discusses at length why markets and government intervention are not mutually exclusive, and how the emergence of markets historically has necessitated actions by the state. Polanyi (1944 [1957]: 3) called the notion of self-regulating markets a 'stark utopia.'

8. See Baker (2009).

9. Galbraith (2008) discusses this in the context of various issues: social security, health care, inequality, unemployment, immigration, global warming, and outsourcing. He argues that both conservatives and liberals accept that policy must work through the market. Liberals conceive of market failure that occurs from time to time, and thus offer ways to perfect markets, taking for 
as identified by James Galbraith (2008), is the liberal response to any conflict of livelihood and the social costs of business enterprise. Second, the idea of public interest is the subject to predation on the part of conservatives in state positions who further empower the kept classes. James Galbraith's concept of the 'predator state' is helpful in seeing the erosion of the notion of public interest. He makes a distinction between J.K. Galbraith's industrial state that focused on public investment, and the predator state that seeks to prevent the assertion of public purpose, where '... the very concept of public purpose is alien to, and denied by, the leaders and the operatives of this coalition' (Galbraith 2008: 131). The state structure is utilized not only to direct the social surplus towards the kept classes, but also to launch an opposition to the idea of public interest.

This leads us to the instrumental social value principle, formulated and used within Institutional economics (particularly American Institutionalism): 'the continuity of human life and the noninvidious recreation of community through the instrumental use of knowledge' (Tool 1993: 121). This principle provides non-relativist criteria for evaluating outcomes, including the notion of a public interest conveying the following points: (1) process is at the center of analysis; (2) human life is organized in communities that can be recreated either in invidious or in a non-invidious fashion; (3) communities are recreated through social practices, which include their material provisioning; and (4) there is a common stock of knowledge that can be used either in an instrumental or in a ceremonial way. The ceremonial use of knowledge furthers invidious distinction.

Institutional analysis acknowledges two methods of valuation - ceremonial and instrumental - which form the value structure of a culture. Ceremonial methods of valuation are based on myths and make-beliefs; and instrumental methods of valuation are based on experiment, trial and error, and tools. Myths can obtain the status of knowledge claims and are distinct from instrumentally-warranted knowledge based in problem-solving, experience, and tools. A stretch in the value structure is necessary every time a tool emerges as a problem-solving device. A tool may be 'ceremonially inadequate' - meaning that only the tools that can be reconciled with the existing value structure of the community would be sanctioned for problem-solving purposes (Bush 1987; Todorova 2007).

Government deficits can be viewed as tools that can be used to permit the economy to function at full employment, as well as to achieve other social beliefs, values, and ethical standards. Running government deficits to maintain full employment is technically achievable in an economy with a sovereign currency and flexible exchange rate, but it is ceremonially inadequate because it decreases the power of the vested interests. ${ }^{10}$ The ruling class actively opposes the maintenance of full employment - instead welcoming only stimulus for private sector investment. As explained by Kalecki's 'Political aspects of full employment' (1943 [1990]), there are three main reasons why the business sector dislikes full employment and government deficits. ${ }^{11}$

First, expectations are the main driving forces of private investment. If full employment is to be achieved through private investment, the business sector's state of confidence

granted that such markets exist, and should exist. Galbraith (2008: 152) argues: 'In many cases, the right policy requires limiting, restricting, regulating, disciplining, defeating, or bypassing markets, or even shutting them down. This is not the same as making them work.'

10. For a detailed exposition of the orthodox sound money budget constraint view, as well as a heterodox critique, see Parguez (2002).

11. Kalecki (and Keynes) accept the government budget constraint proposition disputed by functional finance. Many of their followers have disposed of that assumption (Wray 1998; Bell 2001; Parguez 2002; Seccareccia 2012). 
becomes central. Government regulations and actions, as well as workers' demands, are then indirectly controlled by the kept classes through the desire to instill positive expectations of business. Everything that may shake the state of confidence of the 'job creators' must be avoided, and, as prescribed by expert recommendations, the public must go forward with processes such as: deregulation, flexible labor markets, tax cuts, and austerity measures - all in the name of maintaining business sector confidence. However, this device of capitalists' indirect control of the social surplus and social relations would lose its effectiveness once the government begins to maintain full employment through its own expenditures. Consequently, the necessary government deficits are regarded as perilous to the economy and society, and are thus demonized. ${ }^{12}$

Second, capitalists dislike the direction of government spending. Public investment is seen as desirable only to the extent that it does not displace private sector investment and does not decrease profitability. Stabilization of households' consumption is opposed as a matter of principle - even though it increases aggregate business profits. "The fundamentals of capitalist ethics require that "you shall earn your bread in sweat" unless you happen to have private means' (Kalecki 1943 [1990]: 351).

Third, business leaders and their experts dislike the social and political changes resulting from the maintenance of full employment. The problem is not so much the growth of wages, but the undermined social position of the boss. Workers' discipline and strong dependency position as well as the status quo of power are more appreciated than profits by business leaders. 'Their class instinct tells them that lasting full employment is unsound from their point of view, and that unemployment is an integral part of the "normal" capitalist system' (Kalecki 1943 [1990]: 351).

For these reasons, the capitalist government readily engages in stimulating private sector investment during slumps, rather than engaging in maintaining full employment through direct job creation. The method of judging public sector expansion based on its (presumed) effects on private sector investment is grounded in the desire to support vested interests and a status quo distribution and power relations.

Consequently, balancing the government budget is the touted end-in-view of policy formulation. Any enlargement of income policies and public investment undergoes fierce political debate, and painstaking evaluation on the basis of market criteria of success. Fiscal sustainability and 'sound finance' are at the center of these debates and evaluations, while in practice it is the qualitative direction of the government deficits that is kept in check.

As Kalecki brilliantly stated: "The social function of the doctrine of "sound finance" is to make the level of employment dependent on the state of confidence' (Kalecki 1943 [1990]: 350). 'Sound' then means to keep livelihoods subject to the feeble minds of markets - a case of a value structure dominated by ceremonial (pecuniary) valuation and 'imbecile institutions.' The vested interests maintain scarcity, and thus the power to direct and claim the main share of the social surplus - what the ruling class deem to be 'sound.' Consequently, the delineated conflicts of social provisioning persist.

\section{FUNCTIONAL FINANCE AND INSTRUMENTAL SOCIAL VALUE}

The application of a different notion of soundness based on social provisioning rather than pecuniary valuation would require a stretch in the value structure and power relations.

12. For relevant contemporary discussion see Mitchell (2011). 
This would represent a new state of technology for the community - where 'sound finance' is replaced by 'functional finance.'

The term 'functional finance' was used by Abba Lerner as a description of government policy that is designed to obtain full employment and price stability regardless of whether it resulted in growth of government deficits and debt. Lerner's proposition was the first major alternative to the 'crowding out' and 'debt burden' arguments used against government deficit spending. His proposition was that government deficits were not inherently good or bad; instead they should be judged according to their effects on the economy '... and not to any established traditional doctrine about what is sound and unsound' (Lerner 1943: 39). Lerner argued that 'sound finance' is relevant for micro units, and thus was a misguided framework for formulating government policy. Public policy formulation is an altogether different process, and should be formulated based on the outcomes it wanted to achieve for the public purpose. 'The principle of judging fiscal measures by the way they work or function in the economy we may call Functional Finance' (Lerner 1943: 354).

Both post-Keynesians and Institutionalists have found inspiration in the notion of functional finance, and the concept has been 'reinvented' and extended in multiple ways. Most notoriously, some post-Keynesians combined it with Keynes's analysis of persistent unemployment (Vickrey 1986 [2004]; 1996; Forstater 1999); and with Chartalism - Friedrich Knapp's (1924 [1973]) state theory of money approach (Wray 1998; Bell 2001; 2002) and the credit money view (Innes 1913; Ingham 1996), arriving at a neo-Chartalist approach (Wray 2004). That was combined with a sectoral balance approach to the economy (Godley/Wray 1999); Minsky's (1980) financial instability analysis; and with an articulation of monetary operations (Bell 2000; Bell/Wray 2002-2003; Fullwiler 2003), and became known as the Modern Money Theory. ${ }^{13}$

The purpose here is not to detail the developments after Lerner's functional finance proposition, but to emphasize the connections between its basic principles and the social provisioning framework delineated above. For that reason, the discussion is limited to the basic principles of functional finance that served as an impetus to the above work. The broader objective is to work towards grounding the neo-Chartalist or Modern Money Theory in analysis of class, the state, social valuation, and culture.

Lerner proposed functional finance as a '...framework within which all sorts of different policies may be applied' (1951: 134). Lerner thought that it was unscientific to determine what the budget should be before intelligent economic analysis takes place. 'This principle of judging only by effects has been applied in many other fields of human activity, where it is known as the method of science opposed to scholasticism' (Lerner 1943: 354). Applying a fiscal rule (such as the Maastricht rule), government debt-to-GDP ratios, or debt ceilings, is not a policy evaluation. The judgments have been made prior to the selection of that decision rule (Hayden 2006: 33) - namely that government deficits are dangerous, and government debt is a burden. ${ }^{14}$

From an institutional perspective, to be judged, a public action should be evaluated on the basis of public criteria. Government deficits and debt are means for achieving that particular social goal. Do the government deficits and debt contribute to the continuity of human life and the non-invidious recreation of community through the

13. See Modern Money Primer at: http://neweconomicperspectives.org/p/modern-monetarytheory-primer.html.

14. For a critique of such judgments about government deficits and the economy see Vickrey (1996 [2004]). 
instrumental use of knowledge? Applying the Institutionalists' instrumental value principle is a meaningful policy judgment. Targeting pre-determined fiscal rules and purely pecuniary 'sound' debt-to-GDP independently from the reality of the economy is a ceremonial behavior rooted in myth as a way of knowing.

The application of the principles of functional finance in place of the doctrine of 'sound finance,' involves a stretch in the value structure - which could mean an alteration of power relations. Such a stretch of the value structure is yet to occur with respect to maintenance of full employment. Maintenance of full employment within capitalist relations would require direct job creation and public investment (to the extent that it is needed) as well as subsidies to households - directed towards improving lives and enabling income mobility within working classes. As Kalecki (1990 [1943]: 356) puts it:

'Full employment capitalism' will, of course, have to develop new social and political institutions which will reflect the increased power of the working class. If capitalism can adjust itself to full employment, a fundamental reform will have been incorporated in it. If not, it will show itself an outmoded system which must be scrapped.

The creation of a full employment level of effective demand through public investment, direct job creation, and subsidies to households, would necessitate growth of government deficits and debt to the extent that private investment fell short of maintaining a full employment effective demand. Two main questions follow. First, should the resources of the economy be directed towards making it more attractive (profitable) for private sector investment to expand? Second, does the kind of full employment matter? In the context of the delineated social provisioning framework and the instrumental value principle the answer to the first question is: no; and to the second: yes.

First, expanding private investment as an end-in-view in itself necessitates a cumulative and accelerated growth of subsidies to business enterprises, as noted by Kalecki (1945 [1990]: 383). Keynes favored stabilizing private investment - a long-term public policy that was to be directed towards reducing the range of fluctuations of private investment. This was to be achieved by separating the government budget into capital budget and current budget ${ }^{15}$ (Keynes 1980). The government capital budget deals with productive expenditures on investment rather than consumption.

However, given the conflicts discussed above, one problem is that what is deemed productive from the point of view of the business enterprise does not necessarily support the life process. ${ }^{16}$ Furthermore, if labor power is itself produced and households need to channel consumption for that, certain subsidies to household consumption or public funding of health expenditures are also part of investment. However, are these readily accepted by the private sector as legitimate investment expenditures? For one, we come across different definitions of investment - one is based on the ability of individual business enterprises to claim a share of the surplus, and the notion of public investment is based on enlarging aggregate profits. However - as discussed by Kalecki and Veblen - business enterprises are not interested in the expansion of aggregate

15. Vickrey also argued for such a separation of the government budget (2004 [1992]). For detailed discussions of Keynes's view on government deficits and how it differs from Lerner's, as well as of Keynes's concept of 'socialization of investment,' see Kregel (1985); Brown-Collier and Collier (1995); and Seccareccia (2012).

16. Keynes (1980: 291) argued that the public sector should do things that the private sector does not do. This can be taken in two conflicting ways if 'doing' is interpreted as an incomegenerating activity or as an unpaid activity that nonetheless is part of provisioning taking place, even though it is not remunerated. 
profits, but in preserving control by maintaining scarcity. In addition, capitalist expansion involves the creation of 'fictitious commodities' - health being one example. A universal public health program limits that market enlargement. Naturally, capitalists and rentiers are opposing such expansion of the public sector. In the context of the predator state and the liberal 'making markets work' approach, the notion of capital budget could be significantly limited. Consequently, Keynes's socialization of investment is itself a point of conflict of distributing the social surplus.

Second, the kind of full employment economy matters. Is economic activity based on environmental sustainability - is it compatible with the life process? What sectors are expanded? Is the full employment economy centered on promoting invidious distinction? History provides examples of maintaining full employment through largescale state expenditures on armaments and expansion in the armed forces, which ends in wars - in the case of fascism.

Kalecki (1943 [1990]: 356) reminds us that German fascism sprang up against very high unemployment - as a result of the failure of capitalist democracy to secure full employment. Under this system, the dislike of government spending on public investment and consumption is overcome since the expansion of the military sector is accepted as a matter of fact with the help of patriotism, the feeling of threat, and the desire to conquer. Workers' discipline under fascism is maintained by the state through actions ranging from political suppressions of unions to concentration camps (or expansion of the prison industrial complex). The fascist armament economy is an economy of scarcity because it commands the bulk of its resources to a particular sphere, creating a need for getting by with less in other spheres. 'The fascist system starts from the overcoming of unemployment, develops into an armament economy of scarcity, and ends inevitably in war' (Kalecki 1943 [1990]: 352). The fascist armament economy is a special case of a 'target economy' increasingly directing resources to a particular sector (Kalecki 1943 [1990]: 352).

Money manager capitalism ${ }^{17}$ is a 'target economy' that cannot operate at full employment because it thrives on cost shifting and job insecurity.

The evolution of social provisioning under perpetually created scarcity could take on various paths. Given the predator state and the liberal response of making markets work, the benevolence of the state cannot be assumed. Kalecki's conclusion is still valid today: 'The fight of the progressive forces for full employment is at the same time a way of preventing the recurrence of fascism' (Kalecki 1943 [1990]: 356). Consequently, a stretch of the value structure would necessitate reclaiming the notion of public purpose away from the predator state and liberal market-serving policies, to support the life process. That can become operationalized by functional finance.

\section{CONCLUSION}

The framework of social provisioning gives a structural and institutional grounding for functional finance. This enables a critical conceptualization of the public sector. The instrumental value principle formulated by Institutional economists allows for a more in-depth analysis of government deficits and full employment. Maintaining full employment is not necessarily consistent with the instrumental value principle of continuity of human life through the non-invidious recreation of community through the instrumental use of knowledge. In that regard, Institutional value theory is of use

17. For a discussion of money manager capitalism, see Wray (2011), for example. 
for post-Keynesian analyses in specifying what type of full employment is to be achieved through functional finance.

The public sector is a manifestation of social values and beliefs, agency, and the political decisionmaking process. However, the public purpose is not a relativist notion - it can be valued by criteria grounded in the knowledge stock accumulated as a result of experience (as opposed to knowledge claims based on myths that are inconsistent with experience). There is nothing subjective about pollution, biodiversity loss, lung cancers, unemployment, hunger, or household debt that restricts human capabilities. There are concrete observations of the life process and instrumental indicators that can be used to evaluate the public sector and to design public policy.

The social provisioning framework, together with the framework of functional finance and the instrumental value principle, moves away from the notion of 'redistribution' used to describe the public purpose. Instead, our eyes should be elsewhere: redistribution occurs every time there is a creation of vested interest in the private sector and when social surplus is claimed as free income by the kept classes. The articulation of the class structure of social provisioning, the way social surplus is generated, and the associated social conflicts, disposes of the assumption of an inherently benevolent state. This paper has aimed at providing the grounds for discussing the ways in which deficit hysteria has become a vested interest itself and an encroachment on the continuation of the life process.

\section{REFERENCES}

Allegretto, S. (2011): The state of working America's wealth, Economic Policy Institute Briefing Paper No. 292, URL: http://www.epi.org/publication/the_state_of_working_americas_ wealth_2011/.

Baker, D. (2009): Free market myth: regulation is everywhere: let's choose who benefits, in: Boston Review, January-February, URL: http://bostonreview.net/BR34.1/baker.

Bell, S. (2000): Can taxes and bonds finance government spending?, in: Journal of Economic Issues, 34(3), 603-620.

Bell, S. (2001): The role of the state and the hierarchy of money, in: Cambridge Journal of Economics, 25(2), 149-165.

Bell, S. (2002): A reply to 'A political economic commentary on government finance and monetary policy', in: Journal of Economic Issues, 36(1), 186-189.

Bell, S., Wray, L.R. (2002-2003): Fiscal effects on reserves and the independence of the fed, in: Journal of Post Keynesian Economics, 25(4), 263-271.

Berger, S. (2009): The normative matrix of social costs: linking Hayden's social fabric matrix and Kapp's theory of social costs, in: Natarajan, T., Elsner, W., Fullwiler, S. (eds), in: Institutional Analysis and Praxis: The Social Fabric Matrix Approach, New York: Springer, 55-67.

Brown-Collier, E., Collier, B. (1995): What Keynes really said about deficit spending, in: Journal of Post Keynesian Economics, 17(3), 341-355.

Bush, P. (1987): The theory of institutional change, in: Journal of Economic Issues, 21(3), 1075-1116.

Charusheela, S., Danby, C. (2006): A through-time framework for producer households, in: Review of Political Economy, 18(1), 29-48.

Dugger, W. (1996): Redefining economics: from market allocation to social provisioning, in: Whalen, C. (ed.), Political Economy for the 21 st Century, Armonk, NY: M.E. Sharpe, 31-43.

Forstater, M. (1999): Functional finance and full employment: lessons from Lerner for today, in: Journal of Economic Issues, 33(2), 475-482.

Fraad, H., Resnick, S., Wolff, R. (1994): Bringing It All Back Home: Class, Gender, and Power in the Modern Household, Boulder, CO: Pluto Press. 
Fullwiler, S. (2003): Timeliness and the Fed's daily tactics, in: Journal of Economic Issues, 37(4), 851-880.

Galbraith, J. (2008): The Predator State, New York, NY: Free Press.

Galbraith, J.K. (1958): The Affluent Society, Bombay, India: Asia Publishing House.

Godley, W., Wray, L.R. (1999): Can Goldilocks survive?, Levy Economics Institute Policy Note 1999/4, URL: http://www.levyinstitute.org.

Gruchy, A. (1987): The Reconstruction of Economics: An Analysis of the Fundamentals of Institutional Economics, New York, NY: Greenwood Press.

Hayden, G. (2006): Policymaking for a Good Society: The Social Fabric Matrix Approach to Policy Analysis and Program Evaluation, New York, NY: Springer.

Herz, T. (2006): Understanding mobility in America, Center for American Progress, URL: http:// www.americanprogress.org/issues/2006/04/b1579981.html.

Himmelweit, S. (1995): The discovery of 'unpaid work': the social consequences of the expansion of 'work', in: Feminist Economics, 1(2), 1-20.

Ingham, G. (1996): Money is a social relation, in: Review of Social Economy, 54(4), 243-275.

Innes, M. (1913): What is money?, in: Banking Law Journal, 30(2), 377-408.

Jennings, A. (1992): Not the economy, in: Dugger, W., Waller, W. (eds), The Stratified State, Armonk, NY: M.E. Sharpe, 117-153.

Jennings, A. (1994): Toward a feminist expansion of macroeconomics: money matters, in: Journal of Economic Issues, 28(2), 555-565.

Jo, T.H. (2011): Social provisioning process and socio-economic modeling, in: The American Journal of Economics and Sociology, 70(5), 1094-1116.

Kalecki, M. (1943 [1990]): Political aspects of full employment, in: Osiatynski, J. (ed.), Collected Writings of Michal Kalecki, Vol. I, Capitalism: Business Cycles and Full Employment, translated by Chester Adam Kisiel, Oxford: Clarendon Press, 347-356.

Kalecki, M. (1945 [1990]): Full employment by stimulating private investment?, in: Osiatynski, J. (ed.), Collected Writings of Michal Kalecki, Vol. I, Capitalism: Business Cycles and Full Employment, translated by Chester Adam Kisiel, Oxford: Clarendon Press, 357-376.

Kapp, K. (1950 [1963]): Social Costs of Business Enterprise, London, UK: Asia Publishing House.

Keynes, J. (1980): Activities 1940-1946 Shaping the Post War World: Employment and Commodities, v. XXVII, London, UK: Macmillan.

Knapp, G. (1924 [1973]): The State Theory of Money, translation of German edition of 1905, Clifton, NY: Augustus M. Kelley.

Kregel, J. (1985): Budget deficits, stabilisation policy and liquidity preference: Keynes's post-war proposals, in: Keynes's Relevance Today, Vicarelli, F. (ed.), London, UK: Macmillan, 28-50.

Lee, F. (2010): Alfred Eichner's missing 'complete model': a heterodox micro-macro model of a monetary production economy, in: Lavoie, M., Rochon, L.-P., Seccareccia, M. (eds), Money and Macrodynamics: Alfred Eichner and Post-Keynesian Economics, Armonk, NY: M.E. Sharpe, 22-42.

Lee, F. (2011): Modeling the economy as a whole: an integrative approach, in: The American Journal of Economics and Sociology, 70(5), 1282-1314.

Lerner, A. (1943): Functional finance and the federal debt, in: Social Research, 10, 38-51.

Lerner, A. (1951): The Economics of Employment, New York: McGraw Hill.

Minsky, H. (1980): Capitalist financial process and the instability of capitalism, in: Journal of Economic Issues, 24(2), 505-523.

Mitchell, W. (2011): Beyond austerity, in: The Nation, 16 March, URL: www.thenation.com.

Nelson, J. (1993): The study of choice or the study of provisioning? Gender and the definition of economics, in: Ferber, M., Nelson, J. (eds), Beyond Economic Man: Feminist Theory and Economics, Chicago, IL: The University of Chicago Press, 23-37.

O'Hara, P. (1995): Household labor, the family, and macroeconomic instability in the United States: 1940s-1990s, in: Review of Social Economy, 53(1), 89-120.

Parguez, A. (2002): A monetary theory of public finance, in: International Journal of Political Economy, 32(3), 80-97. 
Picchio, A. (1992): Social Reproduction: The Political Economy of the Labour Market, New York: Cambridge University Press.

Polanyi, K. (1944 [1957]): The Great Transformation: The Political and Economic Origins of our Time, Boston, MA: Beacon Press.

Power, M. (2004): Social provisioning as a starting point for feminist economics, in: Feminist Economics, 10(3), 3-21.

Prasch, R. (2005): The social cost of labor, in: Journal of Economic Issues, 39(2), 439-445.

Seccareccia, M. (2012): The role of public investment as principal macroeconomic tool to promote long-term growth: Keynes's legacy, in: International Journal of Political Economy, 40(4), 62-82.

Swaney, J., Evers, M. (1989): The social cost concepts of K. William Kapp and Karl Polanyi, in: Journal of Economic Issues, 23(1), 7-33.

Todorova, Z. (2007): Deficits and institutional theorizing about households and the state, in: Journal of Economic Issues, XLI(2), 319-326.

Todorova, Z. (2009): Money and Households in a Capitalist Economy: a Gendered Post Keynesian-Institutional Analysis, Northampton, MA: Edward Elgar.

Tool, M. (1993): The theory of instrumental value: extensions, clarifications, in: Tool, M. (ed.), The Institutionalist Challenge: Beyond Dissent, Norwell, MA: Kluwer Academic Publishers, $119-159$.

Veblen, T. (1899 [1994]): The Theory of the Leisure Class, New York, NY: Dover Publications.

Veblen, T. (1919 [2005]): The Vested Interests and the Common Man, New York, NY: Cosimo Classics.

Veblen, T. (1921): The Engineers and the Price System, Kitchener, ON: Batoche Books.

Vickrey, W. (1986 [2004]): Budget-smudget. Why balance what, how, and when?, in: Forstater, M., Tcherneva, P. (eds), Full Employment and Price Stability: The Macroeconomic Vision of William S. Vickrey, Cheltenham, UK and Northampton, MA: Edward Elgar, 1-9.

Vickrey, W. (1992 [2004]): Meaningfully defining deficits and debt, in: Forstater, M., Tcherneva, P. (eds), Full Employment and Price Stability: The Macroeconomic Vision of William S. Vickrey, Cheltenham, UK and Northampton, MA: Edward Elgar, 27-33.

Waller, W., Jennings, A. (1991): A feminist institutionalist reconciliation of Karl Polanyi, in: Journal of Economic Issues, 25(2), 485-497.

Wolf, E. (2007): Recent trends in household wealth in the United States: rising debt and the middle-class squeeze, Levy Economics Institute Working Paper No. 502, URL: www.levy.org.

Wray, L.R. (1998): Understanding Modern Money: The Key to Full Employment and Price Stability, Cheltenham, UK and Northampton, MA: Edward Elgar.

Wray, L.R. (ed.) (2004): Credit and State Theories of Money: The Contributions of A. Mitchell Innes, Cheltenham, UK and Northampton, MA, USA: Edward Elgar.

Wray, L.R. (2011): Minsky's money manager capitalism and the global financial crisis, in: International Journal of Political Economy, 40(2), 5-20. 